\title{
MICROBIAL ECOSYSTEMS IN SPANISH COASTAL SALINAS; AN ECOLOGICAL AND GEOCHEMICAL STUDY OF BIOMARKERS.
}

\author{
R. de Wit and J. O. Grimalt \\ Dept. of Environmental Chemistry. C.I.D.-C.S.I.C. Jordi Girona 18-26. 08034 Barcelona. Spain.
}

Keywords:Biomarker, Salina, Hypersaline, Microbial mat, Cyanobacteria, Lipids, Highly branched C20 alkene.

\begin{abstract}
Coastal salinas (solar salterns) are human-made environments that comprise an array of evaporation ponds of increasing salinities. Therefore, salinas are appropriate systems to study the biotic communities and the different biogeochemical processes in relation to the water column salinity. At higher salinities the microorganisms are the main organisms; above $300 \mathrm{~g} / \mathrm{l}$ salinity the extremely halophilic archaebacteria predominate. Microbial mats are the conspicuous benthic ecosystems found from 50 to 300 $\mathrm{g} / \mathrm{l}$ salinity.

Lipid biomarkers have been used to trace microorganism and their remains at various depth layers in the sediments covered by the microbial mats. The microscale vertical distribution of some compounds as e.g., a highly branched $\mathrm{C}_{20}$-alkene, is evaluated in relation to the stratification of the bacterial populations. The use of biomarkers in ecology and geology is discussed.
\end{abstract}

\section{INTRODUCTION}

Coastal salinas have been studied frequently by microbiologists and geologists. These human-made ecosystems are extreme environments predominated by microorganisms that represent a source of novel extremophiles. Furthermore, the salinas allow the study of how the salinity determines the composition of the communities. For the geologists the salinas represent a model system to study salt precipitation and related biogeochemical processes in shallow evaporitic environments. The formation of evaporite deposits along the earth history is well documented; about $25 \%$ of the continental areas are underlain by rocks which originated in such environments (BLATT et al., 1980).

We have chosen the salinas within the framework of our multidisciplinary studies on organic geochemistry and microbial ecology of hypersaline microbial ecosystems. Our interest is to trace microorganism by characteristic lipid components. It will be shown that lipid components can be used as biomarkers to analyze the living communities. Furthermore, biomarkers are good tools in palaeolimnological and geological studies, because several organisms leave lipid traces in the sedimentary record. First, the features of the coastal salinas and their biota will be treated in detail. Subsequently, the use of biomarkers in microbial ecology

Limnetica, 8: 205-212 (1992)

(C) Asociación Española de Limnología, Madrid. Spain and organic geochemistry will be discussed using some examples from our work as an illustration.

\section{THE COASTAL SALINAS AND THEIR BIOTA}

Salinas are human-made environments that are exploited to obtain halite $(\mathrm{NaCl})$ for human consumption and industrial purposes. The process is based on the evaporation of brines using the sun and the wind as the energy sources. Thus, salinas are restricted to areas with climates characterized by periods during which evaporation exceeds precipitation such as the Mediterranean region. In Spain salinas are found on the coast and were common inland. Coastal Atlantic salinas are found as far north as the French Bretagne (POISBEAU-HÉMERY, 1980) and even on the river Mersey (Manchester, U.K.).

Figure 1 gives a distribution map of the coastal salinas that are actually exploited in the Spanish part of the Iberian peninsula and the Balearic islands. Most salinas are located along the Mediterranean coast, but some are found along the Atlantic coast in the provinces of Huelva and Cadiz. A comparison of figure 1 with the maps provided by LEFOND (1969) and DRONKERT (1985) demonstrate that the number of coastal salinas under exploitation has declined 


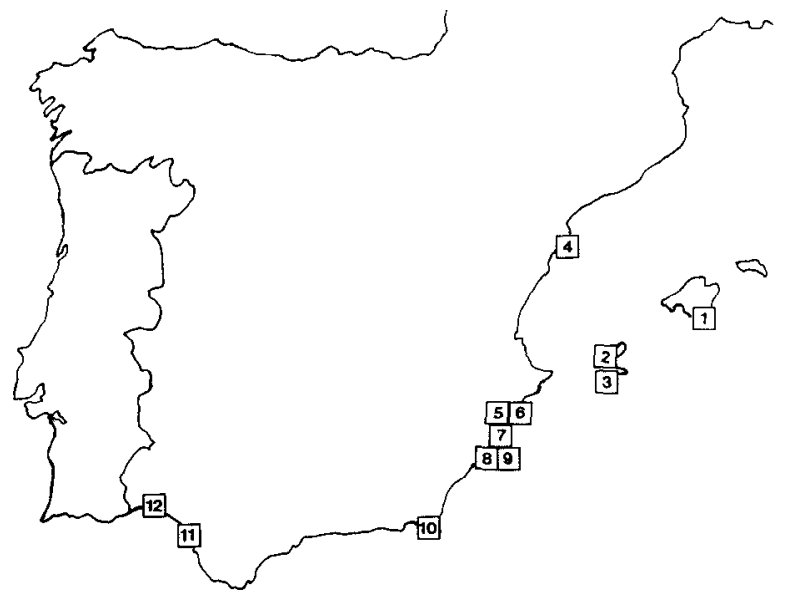

Figure 1. Map of the coastal salinas that are actually exploited in Spain (Peninsula and Balearic Islands).

dramatically during the last two decades. This is the result of low salt prices on the international market due to competition from fossil salt mines, the need for mechanization of the exploitation and the high prices paid for the urbanization of coastal areas.

Most coastal salinas use marine water (thalassic waters), which has a very constant ionic composition world round. In Spain, the salina of Torrevieja ( $N$ o 7 in fig. 1) is an exception because it is fed with a mixture of marine water and brine obtained from Triassic salt rocks. In the Atlantic salinas, the sea water intake normally proceeds at high tide through a system of channels; at decreasing tide, sluices are closed to keep the sea water in these systems. In the Mediterranean region, this system is less efficient due to the small tidal difference. Formerly, seepage through dune barriers used to feed the ponds in some salinas. Presently, however, pumping is used instead of or in addition to direct inflow arid seepage.

A very characteristic continuous process is used to obtain enriched halite in the salinas. Sea water is initially stored in large lagunar shaped ponds, tlie so-called depositos. Subsequently, it flows through a system of consecutive ponds (see fig. 2), while continuously evaporating and concomitantly increasing its salinity. This process results in sequential precipitation of different salts (USIGLIO, 1848) which is shown in figure 2. First, sea water is reduced to approximately $1 / 5$ th while calcium carbonate precipitates and, subsequently. to approximately $1 / 10$ th of the original volume while gypsum precipitates. The brine thus obtained is used to feed the cristalizers where halite is obtained. Finally, a brine highly enriched in potassium salts remains, which only comprises $1 \%$ of its original volume. These brines are called bitterns, and, generally, are either discarded into the sea or used to wash the halite. As a result from this exploitation, a salina encompasses a salinity gradient ranging from sea water $(37 \mathrm{~g} / \mathrm{l})$ up to halite saturation $(350-370 \mathrm{~g} / \mathrm{l})$, corresponding to domains characterized by the precipitation of calcite, gypsum and halite (fig. 2).

The most effective exploitation of the salinas depends on the constancy of the salinities of the different ponds in the array. Therefore, the salinity in the ponds is checked repeatedly and the water flow readjusted in order to prevent salinity fluctuations. The salt concentrations are monitored by density measurements which are expressed in degrees Baumé (Specific Density $=145 /\left(145-{ }^{-} B\right.$ Bé) $\mathrm{kg} / \mathrm{l}$ ). Not all salinas are exploited on a year round basis. Especially in the northern salinas, as e.g., in "Les Salines de la Trinitat", the salinity of the calentadores, cabeceras and cristalizadores decreases during winter. In contrast, in the southeastei-n salinas $\left(\mathrm{N}^{\prime \prime} 5\right.$ -
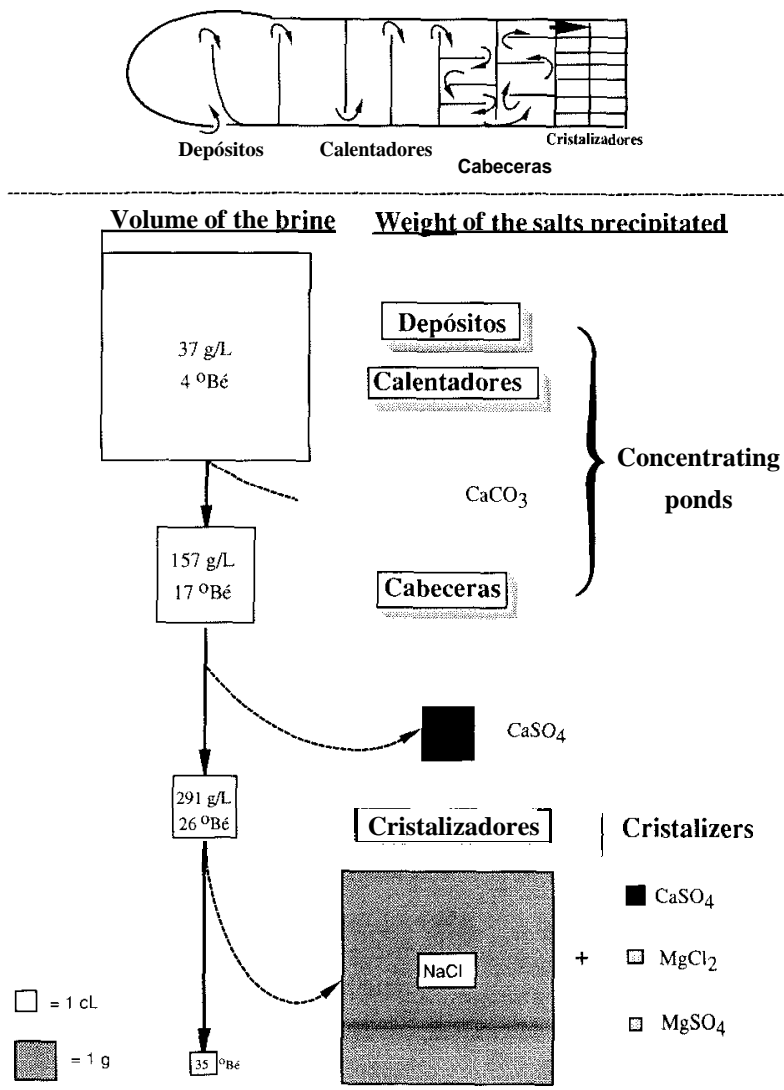

Figure 2. Graphic representation of the brine flon and the evaporation and precipitation processes in Spanish coastal salinas. The names of the different evaporation ponds are given in Spaniah and in English. 
10 in fig. 1), the salinity gradient is maintained throughout the year, hence, gypsum and halite precipitation are even observed in winter, albeit at very reduced rates. These salinas represent an ideal site for scientific research, because they can be studied as a model system in which the biotic communities and the different biogeochemical processes can be related directly to the salinity of the water column.

The biota found in hypersaline environments have been extensiveiy reviewed by JAVOR (1989). The orange-red and the pink to purple-red colours of the most concentrated cabeceras and the cristalizadores ponds, represent perhaps the most well-known feature of the salinas. These colours are due to carotenoids in planktonic microorganisms; orange-red is related to the presence of the halophilic alga Dunaliella; pink to purple-red indicates the presence of extreme halophilic bacteria that predominate at salinities exceeding $300 \mathrm{~g} / \mathrm{l}$. These extreme halophilic bacteria combine with methanogens and thermoacidophilic bacteria, forming the kingdom of the archaebacteria, that possess features which distinguish them sharply from both the eukaryotes and the rest of the bacteria (presently named eubacteria). The halophilic archaebacteria have been extensively studied by RODRÍGUEZ-VALERA and coworkers (University of Alicante, Spain). Remarkably, out of 14 halophilic archaebacterial species described in Bergeys Manual of Systematic Bacteriology (GRANT \& LARSEN, 1989), 3 have been originally isolated from Spanish coastal salinas by this group (see table 1).

Salinas are typical exampies of "extreme environments" in the sense that only a limited number oftaxonomic groups is present. Fishes, macrophytes, i.e. Ruppia maritima, and macroalgae, e.g., Cladophora spp., are found only in low salinity ponds (up to approximately $60 \mathrm{~g} / \mathrm{l}$ ). The invertebrate fauna has been studied extensively in the French Mediterra- nean salina the Salin de Giraud (BRITTON \& JOHNSON, 1987). It was observed that as the salinity increases the diversity of invertebrate species decreases. The depositos have an invertebrate fauna poorer than the sea. The drop of invertebrate species numbers is most pronounced from 40 to $70 \mathrm{~g} / \mathrm{l}$ salinity. At $300 \mathrm{~g} / \mathrm{l}$ salinity only the brine shrimp Artemia salina remains. RODRÍGUEZ-VALERA et al. (1981, 1985) studied the planktonic microorganisms along the salinity gradient. Up to $250 \mathrm{~g} / \mathrm{l}$ salinity, the planktonic communities consist of halotolerant and halophilic microalgae and eubacteria, whereas the halophilic archaebacteria predominate above $300 \mathrm{~g} / \mathrm{l}$.

The reduced activities of macrophytes and invertebrate animals, allow the proliferation of benthic cyanobacteria resulting in the formation of microbial mats. Figure 3 gives a schematic representation of the different microbial mat communities found along the salinity gradients in the salinas. This figure has been compiled from personal observations and previous reports (THOMAS, 1984; NOËL, 1984; CORNÉE, 1984). Microbial mats do occur from 50 up to $300 \mathrm{~g} / \mathrm{l}$ salinity. In the lowest salinity range, mats consist of a top layer of the cyanobacterium Phor-midium valderianum underlaid by Beggiatoa sp. and filamentous heterotrophic bacteria that can be grown chemoorganotrophically on pepton and yeast extract under anoxic conditions. Subsequently, mats can be found that consist of the ubiquitous cyanobacterium Microcoleus chthonoplastes accompanied by purple sulphur bacteria and the green filamentous bacterium Chloroflexus that has only recently been cultured by LARSEN et al. (1991). Above $150 \mathrm{~g} / \mathrm{l}$ salinity, the microbial mats have a typical undulated structure with gypsum crystals incrustations. The dominant cyanobacterium is Aphanothece sp. accompanied by layers of the purple sulphur bacteria Chromatium salexigens and Thiocapsa halo-

Table 1. Halophilic archaebacteria (fam. Halobacteriaceae) originally isolated from Spanish Salinas by F. Rodríguez Valera and coworkers.

\begin{tabular}{lll}
\hline Organism: & Morphology: & Special features: \\
\hline Haloferax mediterrani & flattened disk or cup & uses starch, found at \\
salinities $>100 \mathrm{~g} / \mathbf{l}^{(1)}$ \\
Haloferax gibbonsii & flattened disk or cup & does use starch \\
Haloarcula hispanica & small pleomorphic rods & uses starch \\
\hline
\end{tabular}

(1) In the natural environment, the other members of the Halobacteriaceae do not occur in high densities at salinities below 250 $\mathrm{g} / \mathrm{l}$. 


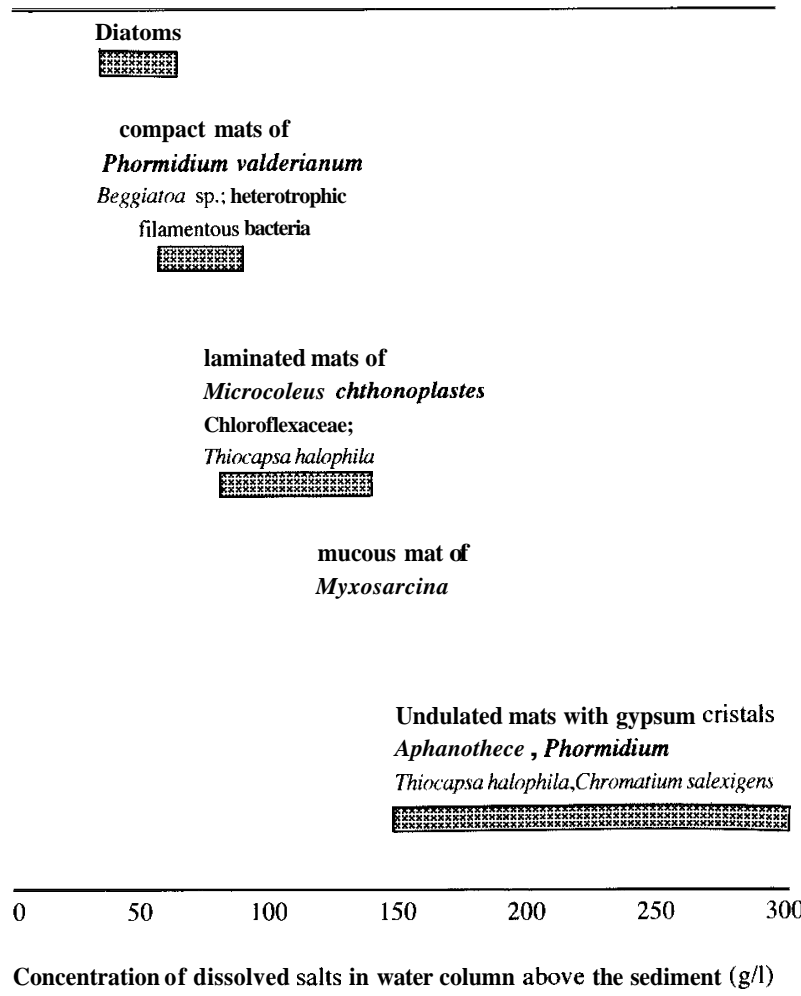

Figure 3. Microbial inat communttes found in Spanish coastal salinas at various dissolved salt concentrations.

phila that have been isolated recently by CAUMETTE $e t$ al $(1988,1991)$ from French salinas.

\section{THE BIOMARKER CONCEPT.}

The use of "biomarkers" in microbial ecology and in organic geochemistry is based on the observation that some compounds are exclusively synthesized by certain taxa of organisms. The compounds most frequently used comprise photosynthetic pigments and fatty compounds. A extensive reference on lipids in microorganisms of different groups is given in RATLEDGE \& WILKINSON (1988). The phospholipid bilayers of the cellular membranes are the main source of fatty acids, steroids and hopanoids. The rapid development of gas chromatography (GC) and GC coupled to mass spectrometry (GC-MS) has enabled the identification and quantification of lipid compounds in environmental samples of small size. Commonly, mixtures of (2:1) methylene chloride-methanol are used to extract the lipids from the samples. The extracts are saponified to recover fatty acids from phospholipids (so-called phospholipid-linked fatty acids). Subsequently, fractionation techniques are used to aeparate the lipid mixtures in hydrocarbon, ketone, aidehyde, alcohol and fatty acid fractions. These procedures have been described in detail by ALBAIGÉS et al. (1984), BARBÉ et al. (1991) and others.

In microbial ecology a "biomarker" has been defined as "chemical components of microorganisms which can be analyzed directly from the environment and be interpreted both quantitatively and qualitatively in terms of in situ microbial biomass" (PARKES, 1987). Presently, the qualitative and quantitative determination of the bacterial species present in ecosystems is still unreliable due to technical iimitations. It has been claimed that the classical counting techniques, which involve culturing on agar plates (colony forming units) or in liquid media (most probable number), underestimate the bacterial population by a factor between 10 and $10^{6}$ (PARKES, 1987). Obviously, new techniques are required to get better estimations of microbial biomass and diversity, hence, the use of lipid biomarkers seems a promising tool (PARKES, 1987; VESTAL \& WHITE, 1989). So far, lipid biomarkers have proven to be especially useful for tracing various groups of sulphate-reducing bacteria in anoxic sediments (TAYLOR \& PARKES, 1985).

In geological chemistry a "biomarker" has been defined as "an organic compound of widespread occurrence in geologic samples that can be related to the original carbon-containing constituents of organisms" (ENGLINTON \& CALVIN, 1967). For example, geological biomarkers indicative of hypersalinity have been recognized by comparison of fossil facies (TEN HAVE et al., 1988), or can be recognized by studying the fate of different compounds in actual ecosystems (see below). In microbial ecology, a biomarker is an actual constituent of a microorganism that ideally disappears upon death. In contrast, in geology, a biomarker has to be conserved after death in its original form or as a post-depositional transformation product. Hence, the ecological and geological biomarker concepts are similar, but can be conflicting in their application. In practice, the living cell comprises a whole range of compounds of different biodegradabilities. For example, adenosine triphosphate (ATP) is a compound found in all living organisms, that rapidly disappears upon cellular death. Hence, ATP is commonly used to estimate the total biomass in different ecosystems. Likewise, phospholipids are believed to have a rapid turnover and, therefore, have also been used to estimate total living biomass (KARL, 1986). In contrast, neutral lipids, steroids and other terpenoid lipids can be preserved for extended periods. However, the conservation and transformation processes strongly depend on the envi- 
ronments of deposition; generally, lipids are best conserved under anoxic conditions.

Our approach is to study the lipids of actually living communities and underlying young sediments in recent ecosystems to assess their usefulness as ecological or geological biomarkers. The sedimentary lipid cornposition has been described for calcite, halite and gypsum domains in the Salinas de Bonmatí (see fig. 1, № 6) (BARBÉ et al., 1990). For example, di-O-phytanyl glycerol (I) was a characteristic compound in salt from the halite dornain relating to the predominance of halophilic archaebacteria. Strikingly, this compound has been found by TEIXIDOR et al. (1991) in Miocene salt deposits in Remolinos mines (Zaragoza) and in the Lorca Basin (Murcia), indicating its excellent properties as a geological biomarker.

More recent studies have been focused on the study of the different rnicrobial mats in the salinas (GRIMALT et al., in press.). Microbial mats are stratified cornrnunities, consisting of millimeter fine laminas. More general information on these sediment ecosystems is provided in COHEN and ROSENBERG (1989); microbial rnats in other environrnents in Spain are described by GUERRERO \& DE WIT (1992, this volurne), and ESTEVE et al. (1992, this volume). Despite the relative abundance of lipid studies of microbial mats, very few have included subsampling procedures that were consistent with the small scale stratification of the microbial populations (e.g., BOON \& DE LEEUW, 1987 for a review). We have performed millimetric scale sampling techniques when studying the mats in the salinas. Furthermore, microorganisms frorn these sites have been obtained in culture. The lipid composition of the different layers has been compared to the vertical distributions of the microbial populations as observed by optic rnicroscopy and to the lipid composition of the enrichment cultures. This comparison has afforded the characterization of the predominant organic matter sources and the extent to which the compounds are conserved and transformed in the young sediments (diagenesis) (GRIMALT et al., in press). Some results from the study of Phorrnidium valderianum -mats are described in the following section.

\section{SOME RESULTS OBTAINED STUDYING PHORMIDIUM -MATS}

The top two rnillimeters of the rnat studied in the Salinas de Bonmatí (fig. 1 № 6 ) was dominated by the cyanobacterium Phorrnidium valderianurn, and Spirulina sp. was present in minor amounts. At approximately $2 \mathrm{~mm}$ depth a fine layer of purple sulphur bacteria was found, mainly consisting of Ectothior-hodospira sp. High densities of conspicuous heterotrophic filarnentous bacteria together with the
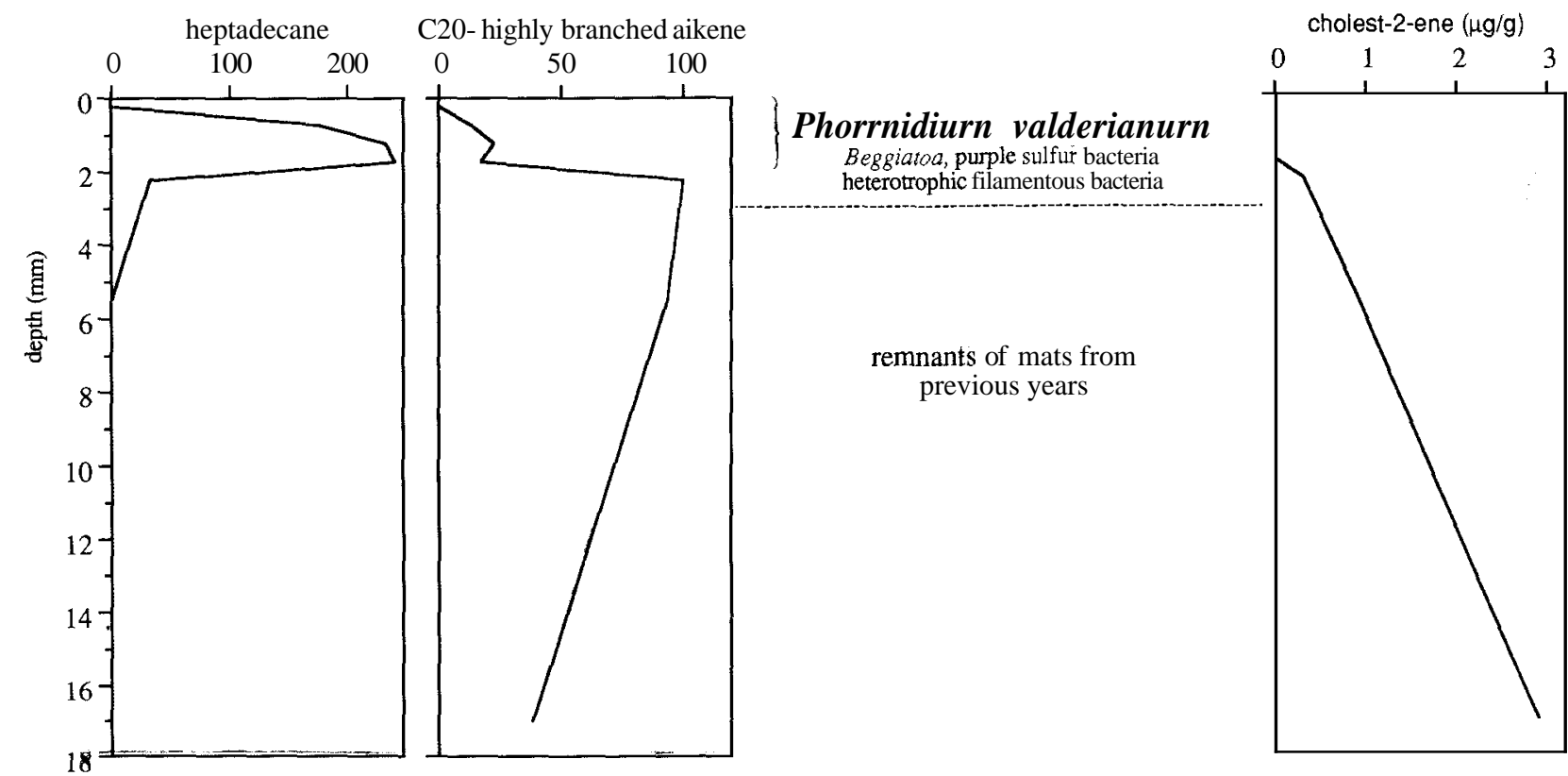

Figure $\$$ : Biological stratificution and vertical profiles of the hydrocarbons heptadecane, highly branched $\mathrm{C} 20$-alkene, and cholest-2-ene observed in Phormidium -mats fram the Salinas de Bonmatí. 
chemotrophic sulphide oxidizer Beggiatoa were found from 1.5 to $3 \mathrm{~mm}$ depth. Below $2.5 \mathrm{~mm}$ depth the sediment was black-coloured indicating continuously anoxic conditions and sulphide production. Bioturbation of these mats was not observed. The laminations below the actually living mat correspond to buried mats of former years. The vertical distribution of some of the hydrocarbons in these sediments is given in figure 4 .

The high amounts of heptadecane in the $0.5-2 \mathrm{~mm}$ sediment sections is related to the presence of the cyanobacteria; this compound has been found in several cyanobacterial and algal species (e.g., GELPÍ et al., 1970) and is the major hydrocarbon in cultures of Phormidium valderianum strain P4. However, this hydrocarbon is virtually absent below 2 $\mathrm{mm}$ depth indicating a rapid degradation. In general, it has been found that the cyanobacteria leave only minor lipid features in the sedimentary record (GRIMALT et al., in press). Thus, heptadecane is a good tracer for living cyanobacteria in these ecosystems.

A most interesting feature is the occurrence of the highly branched $\mathrm{C}_{20}$-alkene (II) in the sediments of the Phormidium -mat; this compound is not found in Microcoleus and Aphanothece -mats. Corresponding $\mathrm{C}_{20}$-alkanes of the same structure have been found in older strata (TEN HAVE $e t$ al., 1988). Strikingly, the highly branched $\mathrm{C}_{20}$-alkene has not been found in cultures of Phormidium ralderianum strain

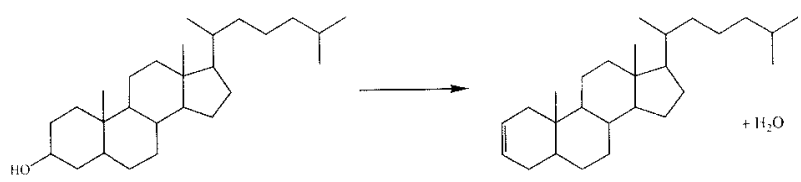

Figure 5. Conversion of cholestan-36-ol into cholest-2-ene (dehydration) that occurs in salina sediinents.

$\mathrm{P} 4$, and its concentration was very low in the top 2 millimeters of the mat considered in this study. Most likely, the compound is synthesized by anaerobic heterotrophic bacteria that grow on the cyanobacterial remains. Nevertheless, the biosynthesis of this compound has not been demonstrated unambiguously by laboratory culture experiments.

The depth profile distribution of another hydrocarbon, cholest-2-ene, is not related to a direct biogenic input, but rather to a diagenetic dehydration of cholestan-3 3 -ol as depicted in figure 5. In addition, various transformation processes are known; concomitantly with dehydration, hydrogenation takes place in layers of strongly reducing conditions (GRIMALT et al., in press).
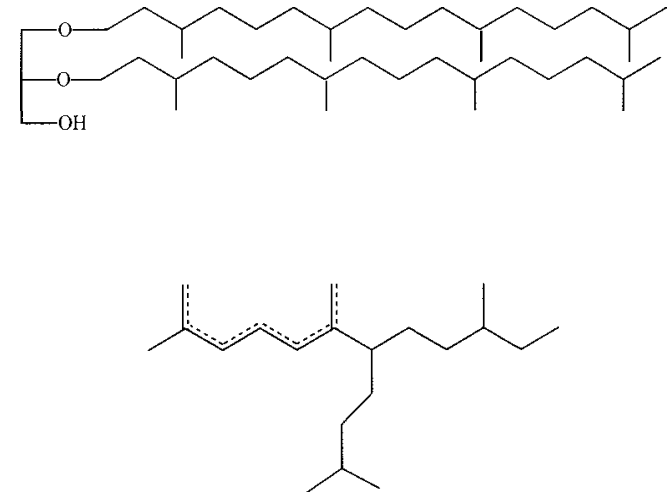

(II)

Figure 6. Sonie compounds cited in the text: $1=$ di-O-phytanyl glycerol: II = highly branched C20-alkene.

In summary, these examples show something of the complex biogeochemistry of the lipid compounds in microbial mat communities. The combination of millimetric scale sampling in combination with culturing experiments provides a useful tool for its understanding. For more detailed information the reader is referred to GRIMALT et al. (in press).

\section{CONSERVATION OF THE SALINA ENVIRONMENTS}

The coastal salinas are very useful for integrated ecological, microbiological and geological research. The biotic communities have a low species diversity, but are highly original because they are composed of extremophiles. Thus, they are a source of novel organisms (see e.g., table 1). The occurrence of these interesting communities is dependent on salt-harvesting activities by human beings. For all these reasons, it is regrettable that many salinas have been abandoned during the last decades.

We strongly recommend all efforts to maintain the interesting salinas in cooperation with the exploiting companies. It is to be hoped that salinas will remain along the Spanish coast for future generations.

\section{ACKNOWLEDGEMENTS}

We are mosı thankful to Dr. Mariona Hernández (Dept. of Natural Products, Faculty of Pharmacy, University of Barcelona) for help in determination of the cyanobacterium Phormidium valderianum. We are indebted to Dr. Francisco Rodríguez-Valera for valuable discussions. Mr. Agustín 
Codina, Mr. Antonio Albalata (UNION SALINERA DE ESPAÑA, S.A.) and Mr. Miguel Cuervo-Arango (Salinas Bras del Port) informed us on the actual exploitation of the Spanish salinas (data used in Figure 1) and granted permission for studying the salinas in Santa Pola.

Rutger de Wit has been supported by grants from the Commission of the European Community (STEP Programme) and the European Environmental Research Organization (E.E.R.O.).

\section{REFERENCES}

ALBAIGÉS, J., ALGABA, J. \& GRIMALT, J.O. 1984. Extractable and bound neutral lipids in some lacustrine sediments. Org. Geochem. 6: 223-236

BARBÉ, A., GRIMALT, J.O., PUEYO, J.J. \& ALBAIGÉS, J. (1990). Characterization of model evaporitic environments through the study of lipid components. Org. Geochem. 16: 815-828

BLATT, M., MIDDLETON, G. \& MURRAY, R. 1980. Origin of sedimentary rocks. 2nd Ed. Pentice-Hall, Englewood Cliffs, N.S.

BOON, J.J. \& DE LEEUW, J.W. 1987. Organic geochemical aspects of cyanobacterial mats. In: P. Fay \& C. Van Balen (Eds.) The Cyanobacteria: 471-492. Elsevier, Amsterdam

BRITTON, R.H. \& JOHNSON, A.R. (1987). An ecological account of a Mediterranean Salina: The Salin de Giraud, Camargue (S. France). Biological Conservation 42: 185-230

CAUMeTte, P.. BAUlaigue, R. \& MATERON, R. 1988. Characterization of Chromatium salexigens sp. nov., a halophilic Chromatiaceae isolated from Mediterranean Salinas. System Appl. Microbiol. 10: 284-292

CAUMETTE, P., BAUlAigue, R. \& MATERON, R. 1991. Thiocapsa halophila sp. nov., a new halophilic phototrophic purple sulfur bacterium. Arch. Microhiol. 155: 170-176

COHEN, Y. \& ROSENBERG, E. Microbial Mats; Physiological Ecology of Benthic Microbial Communities. A.S.M., Washington D.C.

CORNÉE A. 1984. Étude préliminaire des bactéries des saumures et des sédiments des salins de Santa Pola (Espagne). Comparison avec les marais salants de Salin-de Giraud (Sud de la France). Rev. Invest. Geol. 3839: $109-122$

DRONKERT, H. 1985. Evaporite models and sedimentology of Messian and recent evaporites. Ph.D. Thesis. University of Amsterdam.
ENGLINTON. G. \& CALVIN. M. 1967. Chemical fossils. Sit im 216: 32-43

ESTEVE. I., M. MARTÍNEZ, J. MIR \& R. GUERRERO, 1992. Distribution, typology and structure of inicrobial mat communities in Spain. Preliminary studies. Limnetica 8.

GELPI. T. SCHNEIDER. H.. MANN. J. \& (ORO. J. 1970.

Hydrocarbons of geochemical significace in microscopic algae. Phytochemistry 9: 603-612

GRANT, W.D. \& LARSEN, H. 1989. Extremely halophilic archaeobacteria. Order Halobacteriales Ord. Nov. In: J.G. Holt (Ed.). Bergey's Manuel of Systematic Bacteriology. Vol 3: 2216-2236

GRIMALT, J.O., DE WIT, R., TEIXIDOR, P. \& ALBAIGÉS, J. (in press). Lipid biogeochemistry of Phormidium and Microcoleus mats. Adv. of Org. Geochem. Proc. of XV Int. Meeting on Organic Geochemistry. Manchester. 1991

GUERRERO, M. C. \& DE WIT, R. 1992. Microbial mats in the inland saline lakes of Spain. Limnetica 8.

JAVOK. B. 1989. Hypersaline Lmiromments. Microbiology and Biogeochemistry. Springer, Berlin.

KARL, D.M. 1986. Dctermination of in situ microbial biomass, viability, metabolism and growth. In: J.S. Poindexter \& E.R. Leadbetter (Eds.) Bacteria in Nature. Vol. 2. Methods and Special Applications in Bacterial Ecology: 85176. Plenum Press. New York.

LARSEN, M., MACK, E.E. \& PIERSON, B.K. 1991. Mesophilic Chloroflexus -like organisms from marine and hypersaline environments. Abstr. VII. Int. Symp. Photosynthetic Prokaryotes: 169.

LEFOND, S.J. 1963. Handbook of world salt resources. Plenum Press, New York.

NOËL, D. 1984. Les diatomées des saumures et des sédiments de surface du Salin de Bras del Port (Santa Pola province d'Alicante, Espagne). Rev. Invest. Geol. 38-39: 79-107

PARKES, R.J. 1987. Analysis of microbial communities within sediments using biomarkers. $I n$ : M. Fletcher, T.R.G. Gray \& J.G. Jones (Eds.) Ecology of microbial communities. Society for General Microbiology, London.

POISBEAU-HÉMERY, J. (Ed.), 1980. Marais salants. Connaissance des Richesses naturelles de la Loire-Atlantique. Société des Sciences naturelles de l'Ouest de la France, Nantes.

RATLEDGE, C. \& WILKINSON, S.G. (Eds.), 1988. Microbial lipids. Academic Press, London

RODRÍGUEZ-VALERA, F., RUIZ BERRAQUERO, F. \& CORMENZANA, R. 1981. Characteristics of the heterotrophic bacterial populations in hypersaline environments of different salt concentrations. Microbiol. Ecol. 7: 235-243 
RODRÍGUEZ-VALERA, F., VENTOSA, A., JUEZ, G. \& IMHOFF, J.F. 1985. Variation of environmental features and microbial populations with salt concentration in a multipond saltern. Microbiol. Ecol. 11: 107-115

TAYLOR, J. \& PARKES, R.J. 1985. Identifying different populations of sulphate-reducing bacteria within marine sediment systems, using fatty acid biomarkers. J. Gen. Microbiol. 131: 631-642

TEIXIDOR, P., PUEYO, J.J., RODRÍGUEZ-VALERA, F. \& GRIMALT, J.O. 1991. Alkylglycerol diethers in recent and ancient evaporites. In: D.A.C. Manning (Ed.). Organic Geochemistry. Advances and applications in the natural environment: 563-565. Manchester University Press, Manchester

TEN HAVE, H.L., DE LEEUW, J.W., SINNINGHE DAMSTE, J.S., SCHENK, P.A., PALMER, S.E. \& ZUM-
BERGE, J.E. 1988. Application of biological markers in the recognition of palaeohypersaline environments. In: A.J. Fleets, K. Kelts, \& M.R. Talbot (Eds.). Lacustrine Petroleum Source Rocks: 123-130. Geological Society Special Publication № 40 .

THOMAS, J.C. 1984. Formations benthiques à Cyanobacteries des salins de Santa Pola (Espagne): composition spécifique, morphologie et caractéristiques biologiques des principaux peuplements. Rev. Invest. Geol. 38-39: 139-158

USIGLIO, J. 1848. Etudes sur la composition de l'eau de la Méditerranée et sur I'exploitation des sels qu'elle contient. Annales des Chem. Phys. 3d. Ser., Vol. XXVZZ: 172-191.

VESTAL, J.R. \& WHITE, D.C. (1989). Lipid analysis in Microbial Ecology. Bioscience 39: 535-541. 